\title{
Life Cycle Assessment of Biodiesel Production from Microalgae: A Mass and Energy Balance Approach in Order to Compare Conventional with in Situ Transesterification
}

\author{
Gorkem Uctug, Divya Naginlal Modi, and Ferda Mavituna
}

\begin{abstract}
The aim of this work was to perform life cycle analyses (LCA) based on detailed process mass and energy balances for the production of biodiesel from microalgae in order to compare the conventional transesterification with in situ transesterification. GaBi software was used to perform the LCA. The material balances revealed that a slightly lower biodiesel yield was obtained for in situ transesterification process $(5.06 \mathrm{~kg} / \mathrm{day})$ when compared to the conventional one (5.5 kg/day). GaBi results showed that the global warming potential (GWP) of the conventional transesterification process was higher than in situ transesterification by $140 \mathrm{~kg} \mathrm{CO}_{2}$ equivalent (per tonne of biodiesel produced). No substantial difference was noted however, for acidification $(4.15 \mathrm{vs} .4 .34 \mathrm{~kg}$ $\mathrm{SO}_{2}$ equivalent), eutrophication (0.641 to $0.666 \mathrm{~kg}$ PO4equivalent) and human toxicity potential $(72.3$ vs. $77 \mathrm{~kg}$ dichlorobenzene equivalent) between the two processes per $\mathrm{kg}$ of biodiesel produced. The results of the LCA analysis also show that electricity production was the major contributor for all the environmental impacts. When both the global warming potential and biodiesel yield were taken into account, it could be concluded that biodiesel production via in situ transesterification was a better option.
\end{abstract}

Index Terms-Biodiesel, environmental impact, life cycle analysis, microalgae, transesterification.

\section{INTRODUCTION}

The increasing demand for energy, the growing fears of climate change and other environmental issues and soaring prices of fossil fuels due to depleting fuel reserves are the main drivers for finding alternative sources of energy which are environmentally friendly [1], [2]. Extensive research has shown that biofuels are capable of replacing conventional fossil fuels in the transportation sector [3] and they have lower carbon emissions. Hence, biofuels are deemed capable of decreasing greenhouse gas emissions arising from the transportation industry [4]. Furthermore, biofuels contribute in reducing the dependency on conventional fuel sources in many countries [4] and they are equally considered to represent and compromise between meeting energy needs without causing further environmental damage [2]. Biodiesel is attracting interest due to several reasons, some of which are the following [5]-[7]:

i) it is biodegradable and has no toxicity characteristics,

Manuscript received August 4, 2017; revised November 20, 2017.

Gorkem Uctug is with the Izmir University of Economics, Faculty of Engineering and Computer Science, Turkey (e-mail: gorkem.uctug@ieu.edu.tr).

Ferda Mavituna and Divya Naginlal Modi are with the University of Manchester, School of Chemical Engineering and Analytical Science, Turkey (e-mail: ferda.mavituna@manchester.ac.uk, divya.naginlal@gmail.com). ii) it has a lower contribution to air emissions,

iii) it can be produced from renewable precursors,

iv) it has negligible sulfur content, superior flash point and higher combustion efficiency

v) and it can be used in vehicles without modifying the engine due to the fact that biodiesel has the same physical and chemical characteristics as diesel.

Biodiesel can be produced via a variety of feedstocks, which are classified according to availability of use for other purposes. First generation feedstock (palm, rapeseed, soybean, coconut) have edible oils that are suitable for human consumption, second generation feedstock consists of oils that are inappropriate for human consumption (jatropha, karanja, jojoba, mahua, waste cooking oil, grease, animal fats), and finally third generation feedstock is defined as new products obtained from biological reactions/processes, such as microalgae [7]. Currently, the two most common feedstocks which are being used for producing biodiesel are rapeseed (in Europe) and soybean (in the United States). However, a debate is ongoing as to whether these two feedstocks should be primarily used as food or as a fuel source [8]. An alternative feedstock for biodiesel production can be algae. Amongst the numerous advantages associated with the latter, the most important one is that algae cannot be used as a food source so the problem of resource allocation between food and energy supply does not apply to the case of biodiesel production from algae [9]. However, it has been reported that it is imperative to have technological breakthroughs in the processing of algae so as to lower the environmental impacts below that of fossil fuel-based diesel [10], [11].

There have been several life cycle assessment (LCA) studies on algal biodiesel production but these have not considered mass and energy balances. The scope of this paper therefore, is to apply the mass and energy balance principle to perform a "gate to gate" LCA on biodiesel production from microalgae. The objectives of our study are as follows:

vi) To build two hypothetical models of microalgal biodiesel production. The former model is based upon the information available from literature on biodiesel production from Chlorella using raceway ponds of seawater in India with the conventional transesterification. The model consists of using an alternative route that uses in situ transesterification, which is believed to be more efficient. These models are considered herein so as to determine whether in situ transesterification has a lower environmental impact.

vii) To perform a mass and energy balance on the models for the process. The aim of performing these balances is to 
build the inventory analysis which will then be used to perform the LCA.

viii)To analyse several examples of environmental impact based on the data obtained from the mass and energy balances and comparison among such instances so as to determine the best route of biodiesel production from microalgae.

\section{Methodology}

\section{A. Biodiesel Production from Microalgae}

There are several major and minor processes associated with the production of biodiesel from microalgae. These processes are summarised in Table I.

TABLE I: Major And Minor Processes in Biodiesel Production from MICROALGAE

\begin{tabular}{ll}
\hline \multicolumn{1}{c}{ Process } \\
Classification & Unit Process \\
\hline & Cultivation \\
& Harvesting \\
Oil extraction & Transesterification and in situ transesterification \\
& Anaerobic digestion \\
& Transportation of biomass within the industry \\
& through a belt conveyor \\
& Separation of algal residue from oil \\
& Hexane and methanol recovery from oil \\
& Neutralisation of catalyst \\
Minor & Separation of glycerol from biodiesel \\
& Purification of biodiesel \\
\hline
\end{tabular}

Since the main novelty of this paper is to compare two different transesterification methods, we believe that a special focus should be given to transesterification. Transesterification can be defined as the process whereby triacylglycerols (TAGs) are converted into fatty acid methyl esters (FAME) in the presence of an alcohol and a catalyst [12].

In situ transesterification, on the other hand, consists of performing oil extraction and conversion of oil into biodiesel through a single step. The advantages of in situ transesterification over conventional transesterification is the reduction in the manufacturing cost due to the elimination of certain unit processes such as oil extraction using hexane, and simplicity of system design and operation [13], [14]. However, in situ transesterification has certain disadvantages as well such as the decrease in the biodiesel yield and the increased consumption of chemicals due to the requirement of a higher ratio alcohol-oil ratio [15].

\section{B. Mass and Energy Balance Approach}

Since there are no known existing commercial plants which produce biodiesel from microalgae [16], the models used in this research were built based on the information available from the literature, especially for the cultivation of the microalgae as shown in Table II. In this paper, the inputs and outputs were determined using a chemical engineering approach, that is, mass and energy balances rather than just collecting data about the process. Although biodiesel production from microalgae is still in its infancy on the commercial scale, much research has been carried out about the unit operations involved in the process. In this study, two scenarios of mass and energy balances have been carried out.
The first scenario (also referred to as the baseline scenario) consists of using the conventional method of producing biodiesel whereas the second scenario (in situ transesterification) involves using a more advanced technology so as to minimise cost and process units. Detailed information about the mass and energy balances can be found elsewhere [17].

TABLE II: DATA FOR THE MASS AND ENERGY BALANCE CALCULATIONS

\begin{tabular}{lll}
\hline \hline Parameters & Values & References \\
\hline $\begin{array}{l}\text { Maximum specific } \\
\text { growth rate }\end{array}$ & $0.041 \mathrm{~h}^{-1}$ & {$[18]$} \\
$\begin{array}{l}\text { Initial dissolved } \mathrm{CO}_{2} \\
\text { concentration }\end{array}$ & $0.013 \mathrm{~mol} \cdot \mathrm{m}^{-3}$ & \\
$\begin{array}{l}\text { Michaelis- Menten } \\
\text { constant of } \mathrm{CO}_{2}\end{array}$ & $0.00021 \mathrm{~mol} \cdot \mathrm{m}^{-3}$ & \\
$\begin{array}{l}\text { Surface area of raceway } \\
\text { pond }\end{array}$ & $10,000 \mathrm{~m}^{2}$ & {$[19,20]$} \\
$\begin{array}{l}\text { Depth of raceway pond } \\
\text { Biomass concentration in } \\
\text { pond }\end{array}$ & $20 \mathrm{~cm}$ & $0.1 \mathrm{~g} \cdot \mathrm{L}^{-1}$ \\
$\begin{array}{l}\mathrm{CO} \text { utilization efficiency } \\
\text { Amount of CO }\end{array}$ & $90 \%$ & {$[20]$} \\
$\begin{array}{l}\text { consumed by microalgae } \\
\text { daily }\end{array}$ & $540 \mathrm{~kg}$ & {$[18]$} \\
$\begin{array}{l}\text { CO } \\
\text { Ratio of C:N :P }\end{array}$ & & {$[21,22]$} \\
$\begin{array}{l}\text { Amount of water lost due } \\
\text { to evaporation per square } \\
\text { metre }\end{array}$ & $0.0062 \mathrm{~m}^{3}$ & {$[22]$} \\
$\mathrm{CO}_{2}$ utilization efficiency \\
$\begin{array}{l}\text { Organic carbon content } \\
\text { of microalgae }\end{array}$ & $90 \%$ & {$[11,23]$} \\
\hline
\end{tabular}

\section{Life Cycle Assessment (LCA) Methodology}

The scope of this study consists of analysing $1 \mathrm{~kg}$ of algal biodiesel produced at factory gate through the conventional esterification method and in situ transesterification. System expansion is applied in this study for both production routes, as follows; algal residue is anaerobically digested to produce biogas and is in turn combusted to generate electricity which is used in the cultivation process. Similarly, glycerol is combusted in a furnace to generate heat which is used within the biodiesel production process. The environmental impacts were calculated by using GaBi software with CML2001 methodology. The main reason behind this choice is that the same methodology has been adopted by several authors [11], [16] who previously carried out LCA research on biodiesel. The biodiesel production is assumed to take place in India using raceway ponds with seawater.

The system boundary for the production of biodiesel through the conventional method and in situ transesterification are represented by Fig. 1 and Fig. 2, respectively. The following unit processes have not been considered in this project:

- construction of the biodiesel plant;

- transportation of raw materials and of process equipment;

- manufacturing process of raw materials (except electricity) and process equipment;

- transportation of biodiesel to the filling station, and;

- combustion of the biodiesel produced.

Detailed information about the LCA inventory can be found elsewhere [17]. 


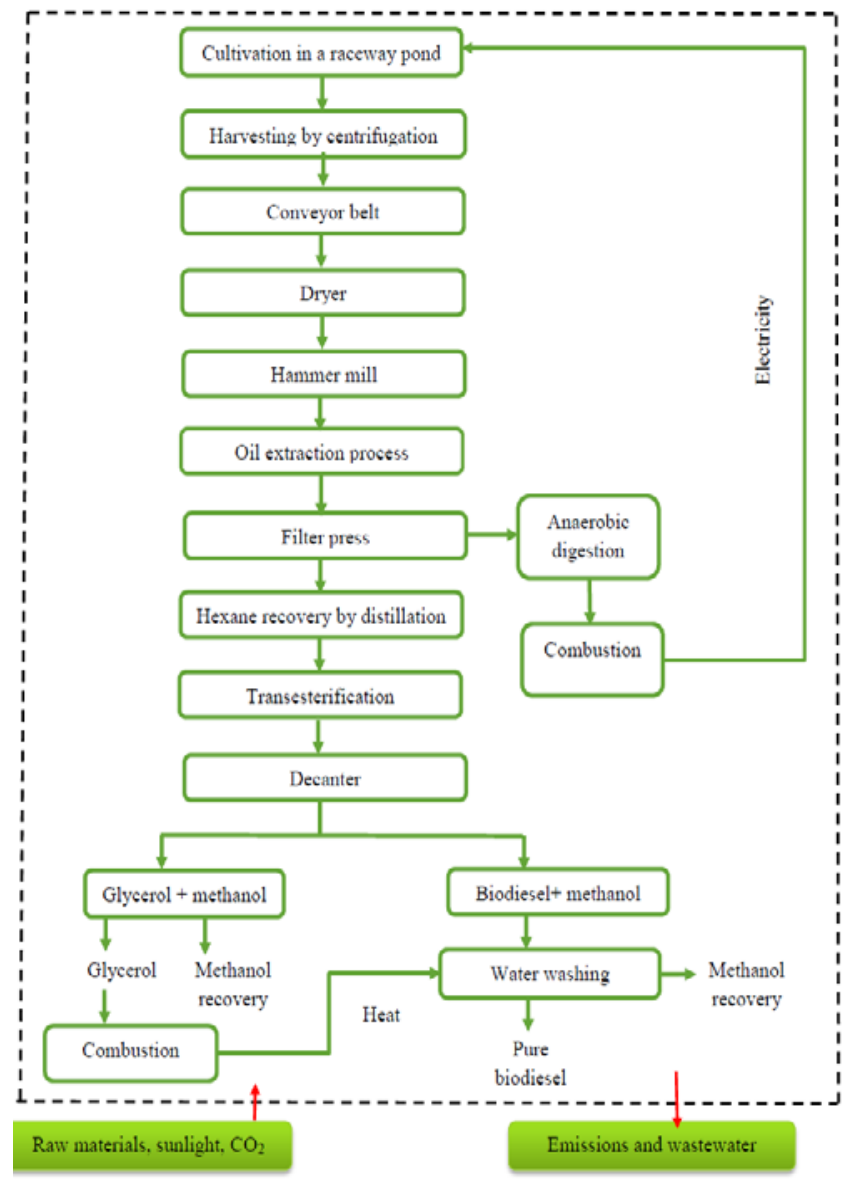

Fig. 1. System boundary for conventional algal biodiesel production.

In the two models salt water algae such as the genus Chlorella is used. The cultivation is based on open raceway ponds with the injection of carbon dioxide (flue gas). Paddlewheels are used in order to provide mixing of the dissolved carbon dioxide and other nutrients, sodium nitrate and diammonium phosphate solution. The operating period for the raceway pond is assumed to be 10 hours. During the night, it is assumed that the algae will not grow.

Algal oil was assumed to consist only of linoleic acid (C18:2) since it has been observed to be the most abundant fatty acid present in microalgae [26]. Linoleic acid was therefore used in the estimation of the stoichiometric carbon requirement by microalgae for the formation of the fatty acids.

\section{RESUlTS AND DISCUSSION}

Fig. 3 below shows the comparative impact results for conventional and in situ transesterification, as well as the yield scores for each technology.

\section{A. Global Warming Potential}

Based on Fig. 3, it is estimated that irrespective of the method of biodiesel production considered, an average of $2.26 \mathrm{~kg} \mathrm{CO}$ eq. per kilogram of biodiesel produced is emitted. The results from the GaBi software revealed that in both scenarios, electricity production is the major process which contributes most to the release of GHG gases. In this work, electricity production has been modelled using coal as its precursor material. Using coal as a raw material for electricity production leads to the release of massive amounts of $\mathrm{CO}_{2}, \mathrm{CH}_{4}$ and $\mathrm{NO}_{\mathrm{X}}$. The $\mathrm{CO}_{2}$ emission, which is reported in the $\mathrm{GaBi}$ software to contribute to global warming, is, in fact, the excess $\mathrm{CO}_{2}$ not consumed by the microalgae and, consequently, released into the atmosphere. In order to further increase the amount of $\mathrm{CO}_{2}$ consumed by microalgae, new approaches to facilitate $\mathrm{CO}_{2}$ consumption by the algae must be developed.

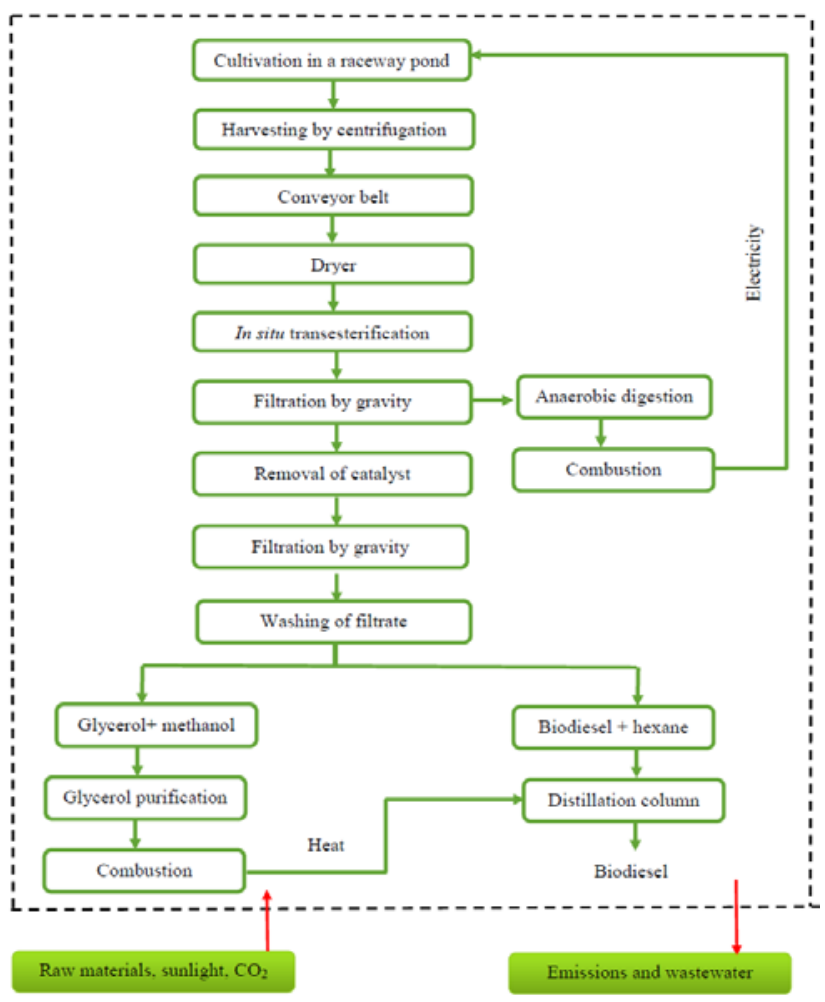

Fig. 2. System boundary for in-situ transesterification in algal biodiesel production.

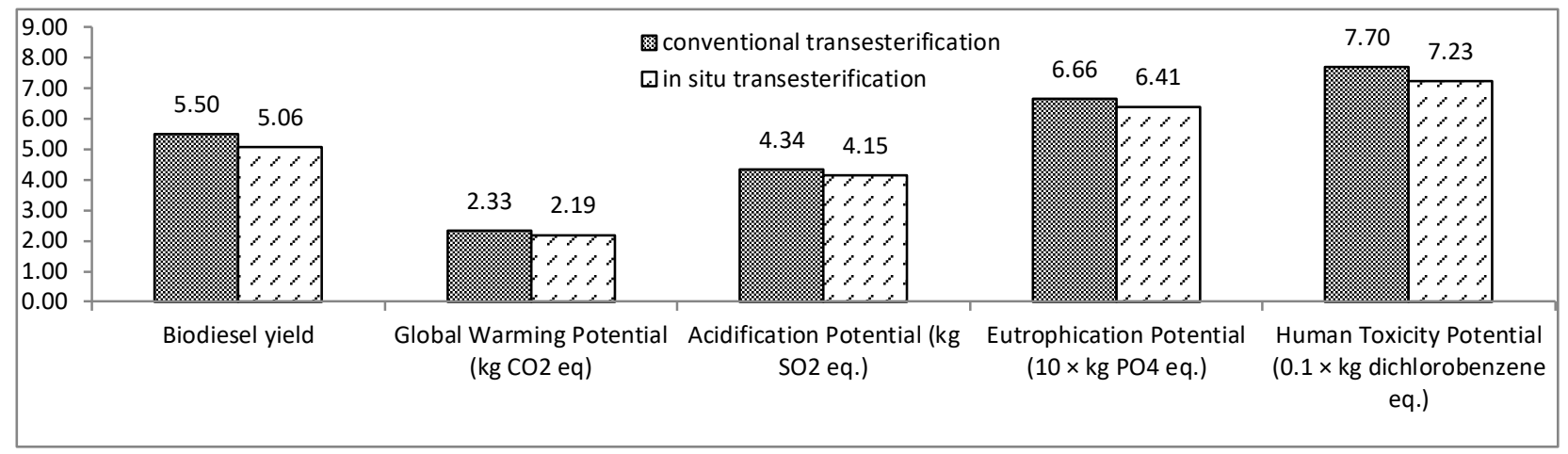

Fig. 3. Yield and impact scores for conventional and in situ transesterification. 


\section{B. Acidification Potential}

The range of acidification potential of microalgal biodiesel production was found to vary between 4.15 to $4.34 \mathrm{~kg} \mathrm{SO}_{2}$-eq. per kilogram of biodiesel produced. The $\mathrm{GaBi}$ analysis proved that electricity and cultivation of microalgae are the major contributors to the effect of acidification. The emissions produced during electricity generation which contribute to the effect of acidification include $\mathrm{NO}_{\mathrm{x}}$, hydrogen chloride $(\mathrm{HCl})$ and $\mathrm{NH}_{3}$. Fertilisers are believed to be the main cause for $\mathrm{NH}_{3}$ emissions [11]. It can be observed that there is a very small difference in the acidification potential between in situ transesterification and conventional transesterification. Hence, it can be argued that this difference is relatively insignificant on an industrial scale, for example for the production of $1000 \mathrm{~kg}$ of biodiesel. The marginal difference is due to the fact that the electricity consumption in in situ transesterification is less than in conventional transesterification.

\section{Eutrophication Potential}

Regardless of the method of biodiesel production considered, the eutrophication potential varies between 0.666 to $0.641 \mathrm{~kg} \mathrm{PO}_{4}{ }^{3-}$ eq. per kilogram of biodiesel produced. The major contributors of eutrophication are electricity production and cultivation of microalgae. $\mathrm{GaBi}$ revealed that $\mathrm{NH}_{3}$ is the major pollutant leading to the effect of eutrophication. Similar findings have been observed in earlier studies [27].

\section{Human Toxicity Potential}

From Fig. 3, it can be speculated that there is a minimal difference of about $6.1 \%$ between the two scenarios. If the above scenarios are modelled for large scale biodiesel production, the savings in terms of human toxicity potential in in situ transesterification are not substantial. Human toxicity is caused mostly through emissions into air, which is equal to $68.2 \mathrm{~kg}$ DCB eq. and $64.1 \mathrm{~kg}$ DCB eq. for conventional and in situ transesterification, respectively (both are expressed in units of kilogram of biodiesel produced). A stage contribution analysis of the $\mathrm{GaBi}$ results showed that electricity production is the sole key contributor to human toxicity. This result conforms to earlier findings [27]. The pollutants released from the production of electricity consist mostly of heavy metals (41.3\%) such as arsenic (+V) and selenium, inorganic emissions to air (23.2\%) and organic emissions to air (23.5\%) for in situ transesterification. This result is in agreement with findings in earlier studies [27] that emissions of heavy metals are responsible for human toxicity.

\section{E. Comparison to Other Studies}

Although there is a considerable number of studies concerning the LCA of microalgal biodiesel in the literature, direct comparison of our results to the results published in those studies proved to be impossible in most cases due to either differences in system boundaries or in functional units. For instance, many studies define the functional unit as the unit amount of energy produced in a vehicle. Furthermore, the type of LCA methodology used (endpoint vs. midpoint) also limits the scope of comparisons of the respective results. Finally, even if the system boundaries, functional units, and methodologies are similar, the impacts calculated in one study may have been overlooked in another. It was therefore only possible to compare the global warming potential results with four other studies. Results of these comparisons are presented in Fig. 4.

Fig. 4. Comparison of Global Warming Potential (GWP) values against other studies.

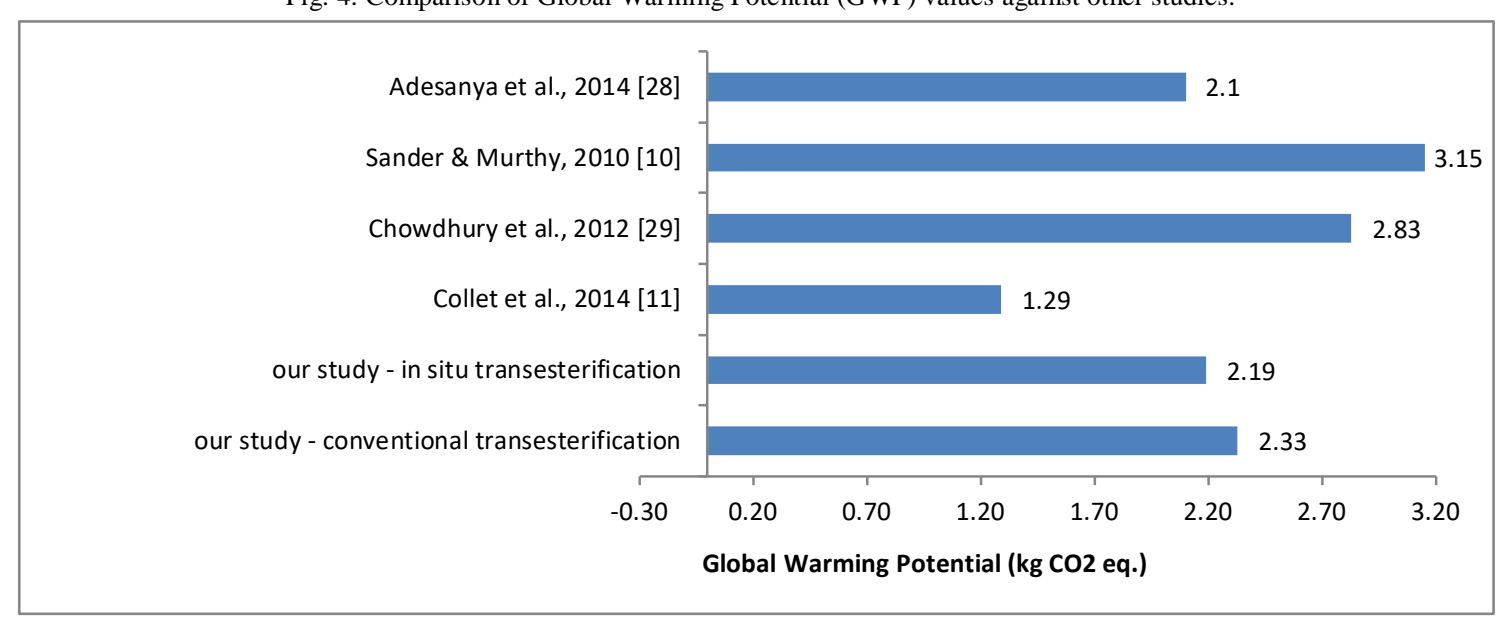

Fig. 4 shows that our results are close to, albeit not the same as, the findings reported in earlier studies. The main differences arise from the environmental qualities of the sources used for electricity generation. For instance, Collet and colleagues [11] used the European electricity mix data, which has much lower GWP impact than the Indian electricity mix, and we believe this to be the main reason behind the considerable difference between their results and ours.

Last but not least, we would like to explain the absence of a sensitivity analysis in this study. Since the present approach is based on a detailed mass and energy balance, we believe that all the inventory data are of high quality and therefore we deem any sort of sensitivity analysis unnecessary.

\section{CONCLUSION}

In this study, two hypothetical models; conventional and in situ transesterification, were developed as potential methods of producing biodiesel from microalgae. The two systems considered for biodiesel production consist of unit operations that were modelled in the best possible realistic way. It can be 
stated that in situ transesterification have never been considered in previous LCA studies on microalgal biodiesel production. A combination of the technologies applied in the downstream processing of first and second generation biodiesel feedstocks were applied to the microalgal biodiesel production systems. Mass and energy balances were performed and used to build the inventory for the LCA on biodiesel production. The material and energy balances carried out indicated that the biodiesel production process has a relatively low efficiency. However, algae can have up to 100 times more oil content when compared to first and second generation feedstocks (energy crops). Also, in situ transesterification has a slightly lower biodiesel yield than the conventional transesterification method. An analysis on the possible environmental impacts that may arise from the biodiesel production process has been carried out. The LCA analysis revealed the following:

- In situ transesterification has been proved to perform better across all the impact categories considered in the present work. This is due to the fact that the conventional transesterification process has slightly higher energy consumption.

- $\quad$ The global warming potential of in situ transesterification is lower than that of the conventional transesterification. The former has a GWP of $2190 \mathrm{~kg} \mathrm{CO}_{2}$-eq. whereas the latter has a GWP of $2330 \mathrm{~kg} \mathrm{CO}$-eq.

- The difference observed amongst the environmental impacts (besides global warming potential) is marginal and consequently, it may not make a significant difference on the consequences of acidification, eutrophication and human toxicity.

- In both scenarios, the effect of acidification has been found to be caused mainly by electricity production and cultivation of microalgae. The use of fertilisers in the cultivation medium has been observed to be responsible for the acidification effect due to the release of $\mathrm{NH}_{3}$.

- $\quad$ Results given by $\mathrm{GaBi}$ revealed that eutrophication is mostly a result of electricity generation and the cultivation process of microalgae. $\mathrm{NO}_{\mathrm{X}}$ and $\mathrm{NH}_{3}$ are the major pollutants released from each of these processes, respectively.

Algal photosynthetic and primary carbon metabolism play a very important role not only in the process economics but also in the LCA-indicated sustainability issues for future considerations of algal hydrocarbon and/or biodiesel production. Strain improvement either through natural mutant identification or genetic manipulations, with the proper containment precautions, should be the alternatives to consider as far as future work is concerned.

\section{REFERENCES}

[1] L. Zhu, et al., "Biodiesel production from algae cultivated in winter with artificial wastewater through $\mathrm{pH}$ regulation by acetic acid," Applied Energy, vol. 128, pp. 103-110, 2014.

[2] United Nations. (2014). The state of the biofuels market: Regulatory. Trade, and Development Perspectives. [Online]. Available: http://unctad.org/en/PublicationsLibrary/ditcted2013d8_en.pdf

[3] J. Malça, A. Coelho, and F. Freire, "Environmental life- cycle assessment of rapeseed-based biodiesel: Alternative cultivation systems and locations," Applied Energy, vol. 114, pp. 837-844, 2014.
[4] DNV 2010 Biofuels 2020. A policy driven logistics and business challenge. [Online]. Available: http://www.dnv.com/binaries/Biofuels\%202020\%20position\%20pape r_tcm4-

[5] I. Bankovic-Illic, O. Stamenkovic, and V. Veljkovic, "Biodiesel production from non-edible plant oils," Renewable and Sustainable Energy Reviews, vol. 16, pp. 3621-3647, 2012.

[6] S. Farell and E. Cavanagh, "An introduction to life cycle assessment with hands-on experiments for biodiesel production and use," Education for Chemical Engineers, vol. 9, pp. 67-76, 2014.

[7] P. Nautiyal, K. Subramanian, and M. Dastidar, "Production and characterization of biodiesel from algae,” Fuel Processing Technology, vol. 120, pp. 79-88, 2014.

[8] X. Deng, L. Yajun, and X. Fei, "Microalgae: A promising feedstock for biodiesel,” African Journal of Microbiology, vol. 3, issue 13, pp. 1008-1014, 2009.

[9] S. Medipally, F. Yusoff, S. Banerjee, and M. Shariff, "Microalgae as sustainable renewable energy feedstock for biofuel production," BioMed Research International, vol. 2015, pp. 1-13, 2015.

[10] K. Sander and G. Murthy, "Life cycle analysis of algal biodiesel," International Journal of Life Cycle Assessment, vol. 15, pp. 704-714, 2010.

[11] P. Collet, et al., "Biodiesel from microalgae- life cycle assessment and recommendations for potential improvements," Renewable Energy, vol. 71, pp. 525-533, 2014.

[12] A. Koutinas and S. Papanikolaou, "Biodiesel production from microbial oil," in Handbook of biofuels production, R. Luque, J. Campelo, and J. Clark, Eds., Cambridge: Woodhead Publishing Ltd., 2016, p. 177.

[13] I. Rawat, R. R. Kumar, T. Mutanda, and F. Bux, "Biodiesel from microalgae: A critical evaluation from laboratory to large scale production,” Applied Energy, vol. 103, pp. 444-467, 2015.

[14] H. He, X. Guo, and S. Zhu, "Comparison of membrane extraction with traditional extraction methods for biodiesel production," Journal of the American Oil Chemists' Society, vol. 83, pp. 457-460, 2006.

[15] P. Hidalgo, et al., "Improving the FAME yield of in situ transesterification from microalgal biomass through particle size reduction and cosolvent corporation,” Energy \& Fuels, vol. 29, pp. 823-832, 2014.

[16] L. Lardon, et al., "Life cycle assessment of biodiesel production from microalgae,” Environmental Science \& Technology, vol. 43, issue 17, pp. 6475-6481, 2009.

[17] N. M. Divya, "Life cycle assessment of biodiesel production from microalgae,” MSc dissertation, The University of Manchester, Manchester, UK, 2015.

[18] H. Lian, V. Subramanian, and Y. Tang, "Experimental analysis and model-based optimization of microalgae growth in photo-bioreactors using flue gas,” Biomass and Bioenergy, vol. 41, pp. 131-148, 2012.

[19] A. Pandey, D. Lee, Y. Chisti, and C. Soccol, Biofuels from Algae, USA: Elsevier, 2014.

[20] M. Borowitzka, "Microalgae in outdoor ponds,” in Algal Culturing Techniques, R. Andersen, Ed., United Kingdom: Elsevier Academic Press, 2005.

[21] A. Demirbas and M. Demirbas, Algae Energy: Algae as a New Source of Biodiesel, London: Springer, 2010.

[22] S. Sudhakar, S. Suresh, and M. Premalatha, "An overview of $\mathrm{CO}_{2}$ mitigation using algae cultivation technology,” International Journal of Chemical Research, vol. 3, issue 3, pp. 110-117, 2011.

[23] J. Rogers, et al., "A critical analysis of paddlewheel-driven raceway ponds for algal biofuel production at commercial scales,” Algal Research, vol. 4, pp. 76-88, 2014.

[24] N. Sazdanoff, "Modeling and simulation of the algae to biodiesel fuel cycle,” B. Eng. Thesis, Ohio State University, 2006.

[25] P. Schlagermann, et al., "Composition of algal oil and its potential as biofuel,” Journal of Combustion, vol. 2012, pp. 1-14, 2012.

[26] J. Lee, et al., "Comparison of several methods for effective lipid extraction from microalgae,” Bioresource Technology, vol. 101, issue 1, pp. 75-77, 2010.

[27] J. Hou, P. Zhang, X. Yuan, and Y. Zheng, "Life cycle assessment of biodiesel from soybean, jatropha and microalgae in China conditions,” Renewable and Sustainable Energy Reviews, vol. 15, pp. 5081-5091, 2011.

[28] V. Adesanya, E. Cadena, S. Scott, and A. Smith, "Life cycle assessment on microbial biodiesel production using a hybrid cultivation system,” Bioresource Technology, vol. 163, pp. 343-355, 2014.

[29] R. Chowdhury, S. Vjamajala, and R. Gerlach, "Reduction of environmental and energy footprint of microalgal biodiesel production through material and energy integration,” Bioresource Technology, vol. 108, pp. 102-111, 2012. 


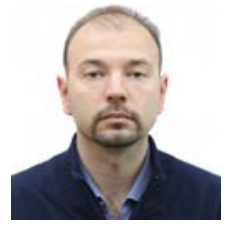

Fehmi Görkem Üçtuğ was born in Ankara, Turkey in 1982. After graduating from Middle East Technical University - Chemical Engineering Department with a GPA of 3.85/4.00- with the First in Class award in 2004, he carried out his PhD studies at the University of Manchester, School of Chemical Engineering and Analytical Sciences between 2004 and 2008. His studies were funded by the Marie Curie Fellowship of the $6^{\text {th }}$ Framework Programme of the European Union. His thesis title was "Synthesis and characterisation of polyvinylalcohol-mordenite membranes and their applications in direct methanol fuel cells".

After returning to Turkey, he completed his compulsory military service and then started working at Bahçesehir University - Energy Systems Engineering Department in 2010, where he had worked as an assistant professor until September 2016. He taught courses such as "Fundamentals of thermodynamics", "Heat and mass transfer", "Fuels and combustion", "Energy economics”, "Sustainable energy", "Fuel cell technologies", "Introduction to energy systems engineering”, "Alternative and renewable energy systems", "Capstone project". He also was the vice-dean of the Faculty of Engineering and Natural Sciences between 2013 and 2016. Between September-December 2016, he worked as a visiting professor at the Sustainable Industrial Systems research group within the School of Chemical Engineering and Analytical Sciences of the University of Manchester.

Since February 2017, he has been working as an assistant professor at Izmir University of Economics (Turkey), Faculty of Engineering and Computer Science. His fields of interest include life cycle assessment, clean carbon technologies, direct methanol fuel cells, energy efficiency in buildings, and optimization.

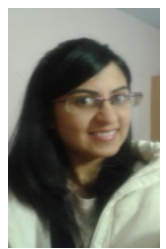

Divya Naginlal Modi was born in Plaines Wilhems, Mauritius in 1991. After graduating from the University of Mauritius in chemical and environmental engineering with a GPA of 3.32/4 in 2014, she pursued her MSc degree in environment and sustainable technology at the University of Manchester, School of Chemical Engineering and
Analytical Science in 2015. During her master’s degree, the title of her thesis was "Life cycle assessment of biodiesel production from microalgae".

After returning to her home country, she was employed as a research assistant at the Mauritius Research Council in June 2016, which is the national body responsible for advising the Government of Mauritius on Science and Technology issues and it influences the direction of technological innovation by funding projects in areas of national priority and encouraging strategic partnerships. Her research projects at the Mauritius Research Council focus in the field of biotechnology. Her research interests are in the following areas: life cycle assessment, industrial ecology, sustainable development, biotechnology, renewable energy, recycling and waste to energy.

Ferda Mavituna is currently a professor of chemical and biochemical engineering in the School of Chemical Engineering and Analytical Science at The University of Manchester, UK. She obtained her degree of BSc in chemical engineering with the Distinction of High Honours and the First Prize in the Department of Chemical Engineering, Middle East Technical University (METU), in Ankara, Turkey in 1973. Her degrees of MSc in advanced chemical engineering and $\mathrm{PhD}$ in chemical engineering were awarded by the Victoria University of Manchester, UK in 1974 and 1979 , respectively. She was chosen for the IChemE and SERC Special Award during 1978-1980 in order to write the biochemical engineering and biotechnology handbook with professor Bernard Atkinson (Macmillan Publishers Ltd). Ferda became a lecturer in the Chemical Engineering Department of UMIST, Manchester in 1980. She was awarded the Senior CIBA-GEIGY Fellowship in 1989 for sabbatical at ETH Zurich. Her research was supported by both industrial companies, notably Albright and Wilson and Kaneka as well as the research councils. Her main research covers specialty chemicals production, such as pharmaceuticals by freely suspended and immobilised microbial, plant and animal cell cultures. In her research, Ferda uses both experimental and theoretical/computational approaches such as kinetics, mass transfer and metabolic flux balance analysis. She has also taught a wide range of chemical engineering and bioprocess engineering courses at graduate and undergraduate levels. 